\title{
Teaching Sustainability in the Chemistry Classroom: Exploring Fuel Cells in Simple Hands-on Experiments with Hydrogen, Sugar and Alcohol
}

\author{
Rebecca Grandrath, Claudia Bohrmann-Linde* \\ Department of Chemistry Education, University of Wuppertal, Gaußstr, 20, 42119 Wuppertal, Germany \\ *Corresponding author: bohrmann@uni-wuppertal.de
}

Received January 14, 2019; Revised February 19, 2019; Accepted April 08, 2019

\begin{abstract}
Energy transition is one of the main global challenges of this century. To realize it and reach the UN's ecological sustainability goals the topic sustainable energy and different ways of approaching energy transition have to be taught at school. As fuel cells can play a key role in the energy turnaround, they should be an integral part in chemistry education. Here we present a series of hands-on experiments focusing on alkaline, microbial and direct methanol fuel cells to help pupils understand how fuel cells work.
\end{abstract}

Keywords: alkaline fuel cell, direct methanol fuel cell, microbial fuel cell, yeast, low-cost materials, hands-on experiments, digital learning tool, education for sustainable development, energy transition, sustainability

Cite This Article: Rebecca Grandrath, and Claudia Bohrmann-Linde, "Teaching Sustainability in the Chemistry Classroom: Exploring Fuel Cells in Simple Hands-on Experiments with Hydrogen, Sugar and Alcohol." World Journal of Chemical Education, vol. 7, no. 2 (2019): 172-178. doi: 10.12691/wjce-7-2-17.

\section{Introduction}

In the year 2015 the United Nations General Assembly defined 17 Sustainable Development Goals as a "shared blueprint for peace and prosperity for people and the planet" to be globally implemented by 2030 [1]. Besides humanistic and economic goals there are also ecological ones (Figure 1):

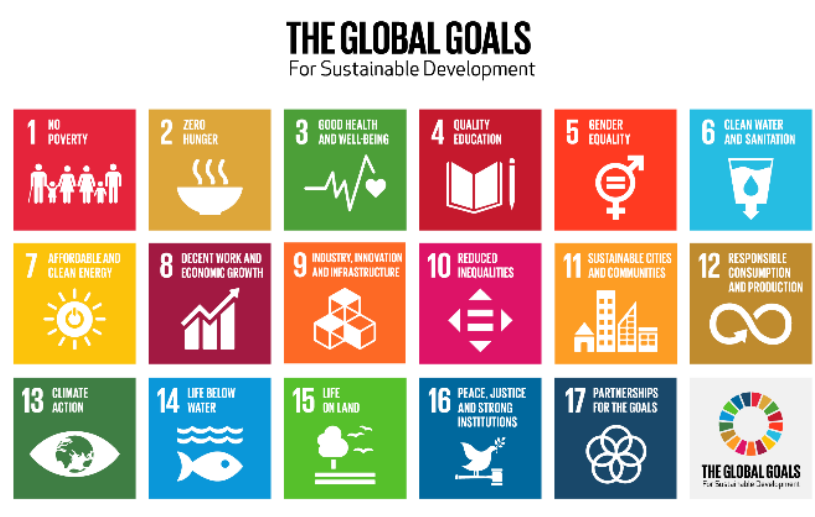

Figure 1. Scheme of the 17 Sustainable Development Goals [2]

Goal 13 "climate action" is to combat climate change and to stop global warming. It particularly specifies an improvement of the education on climate change. Goal 7 "affordable and clean energy" is a mix of ecological and humanistic facets. It is to ensure access to affordable, reliable and sustainable energy for everyone. The amount of renewable energy in the global energy mix is to be considerably increased [3]. In order to be achieved, the Sustainable Development Goals have to be communicated in many ways. School is one of the best places for Education for Sustainable Development (ESD), because it is the institution attended by almost everybody from the generation that brings out the world's future researchers, who are faced with the challenge of a global energy transition.

Fuel cells as a part of a sustainable energy solution are often integrated in the chemistry curriculum in the context of electrochemistry. They could also be addressed in other subjects at school (Figure 2) and thus are a great topic for interdisciplinary learning and for discussions on sustainability from different perspectives. Besides scientific aspects the effect of fuel cells on the socio-economic situation of humans may be subject of such a discussion.

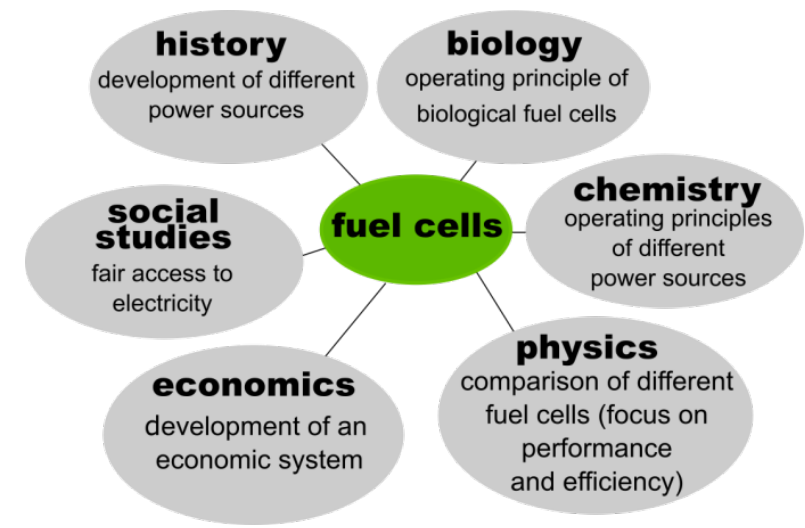

Figure 2. Possible contexts in various subjects, which are suitable for addressing fuel cells and sustainability 
As there is an increase in the use of hydrogen-based Proton Exchange Membrane Fuel Cells (PEMFC) in mobile and stationary applications, these fuel cells are part of the chemistry curricula in Germany and discussed in schools all over the world. Other types of fuel cells are hardly ever considered [4]. Existing school experiments with fuel cells are often based on relatively expensive ready-made hydrogen fuel cells kits (e.g. Figure 5).

In order to enable everyone to carry out experiments with low-budget materials we propose a series of experiments on diverse kinds of fuel cells with low-cost materials that are easy to carry out. The series contains an alkaline fuel cell, a microbial fuel cell and a direct methanol fuel cell and can be integrated into chemistry lessons to show the great diversity of different types of fuel cells (Figure 3 ).

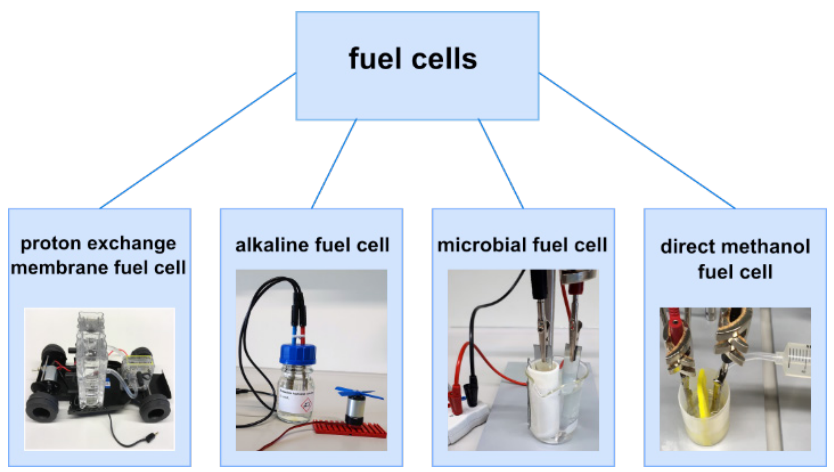

Figure 3. Selected examples of low-temperature fuel cells and possible school experiments

\section{Basic Facts on Fuel Cells}

The term "fuel cell" is used for chemical energy converters that directly transfer chemical energy into electric energy. They are galvanic cells, but in contrast to batteries work based on a continuous fuel supply and the removal of reaction products. Since each reaction with adequate negative free enthalpy can be used in fuel cell systems, a great number of systems coexists. Applications are as diverse as fuels are [5]. Fuel cells are classified due to their operating temperature as low or high temperature systems. In addition, one distinguishes between direct and indirect systems. While direct fuel cells convert the chemical energy of a fuel directly into electricity, indirect fuel cells need a catalyst to generate hydrogen from the fuel (e. g. alcohol, ammonia, cyclohexane or methane) first. The fuel cells presented in this paper belong to the group of direct fuel cells.

Hydrogen driven Proton Exchange Membrane Fuel Cells (PEMFC) are widely known because of their application in electrical vehicles. PEMFC are direct fuel cells working at low temperatures $\left(60-70^{\circ} \mathrm{C}\right)$. The electric efficiency averages about 50-68 \% [5]. Using PEMFCs as an example the general operating principle of a fuel cell can be demonstrated. The basic construction is quite simple (Figure 4).

The PEMFC is composed of inlets for hydrogen and oxygen supply, an outlet for the produced water, (carbon) electrodes as anode and cathode, diffusion layers, a catalyst (mostly platinum) and the Proton Exchange
Membrane. The membrane (e.g. Nafion $®$ ) works as a separator between the electrodes to prevent an electrical shortcut and contains an (acidic) electrolyte.

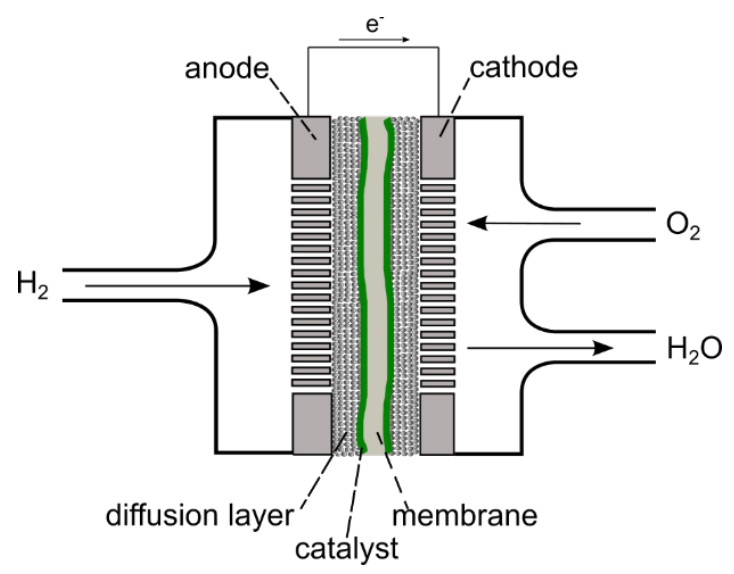

Figure 4. Model of a PEMFC cell

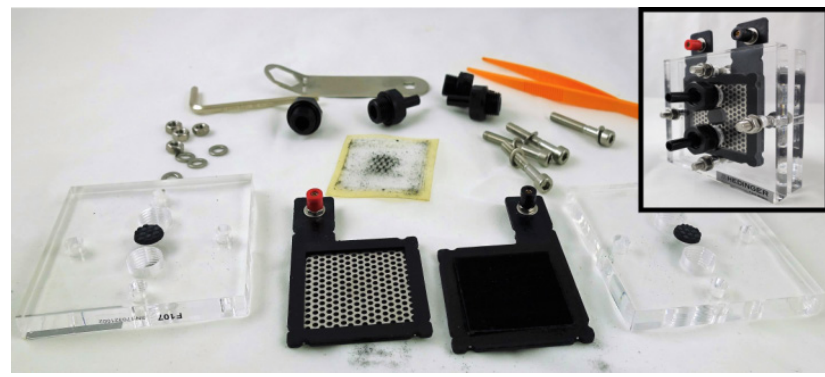

Figure 5. Typical PEM-FC kit: components and complete device

To operate the PEMFC, pure hydrogen is introduced through the anode to the three-phase-border (anode/gas/electrolyte). Here, the hydrogen molecules are oxidised, yielding protons and electrons (eq. 1).

$$
2 \mathrm{H}_{2} \rightleftarrows 4 \mathrm{H}^{+}+4 \mathrm{e}^{-}
$$

The protons pass through the membrane, whereas the electrons move through an external circuit. Consequently, the electrons can be used to run a load before they reach the cathode. At the cathodic three-phase-border protons react with oxygen molecules and electrons forming water molecules (eq. 2):

$$
\mathrm{O}_{2}+4 \mathrm{H}^{+}+4 \mathrm{e} \rightleftarrows 2 \mathrm{H}_{2} \mathrm{O}
$$

The overall reaction (eq. 3) shows, that water is the "waste product" of the FC system.

$$
2 \mathrm{H}_{2}+\mathrm{O}_{2} \rightleftarrows 2 \mathrm{H}_{2} \mathrm{O}
$$

\section{Alkaline Fuel Cells (AFC)}

\subsection{Set-up and Working Principle of AFC}

AFC are also hydrogen-driven and work at low temperatures $\left(20-90^{\circ} \mathrm{C}\right)$, but use an alkaline electrolyte, mostly $30 \%$ potassium hydroxide solution $\mathrm{KOH}$ (aq). Their electric efficiency is about 62-70 \% [5]. Except for the membrane and the alkaline electrolyte the construction is very similar to the PEMFC. Pure hydrogen is the fuel and pure oxygen the oxidising agent. There shouldn't be 
any carbon dioxide in the cell, because this would lead to a clogging of the diffusion layer due to the formation of potassium carbonate (eq. 4):

$$
2 \mathrm{KOH}+\mathrm{CO}_{2} \rightarrow \mathrm{K}_{2} \mathrm{CO}_{3}+\mathrm{H}_{2} \mathrm{O}
$$

Even under alkaline conditions hydrogen is oxidised at the anode (eq. 5), and oxygen is reduced at the cathode (6), so that water is formed as "waste" again (eq. 7):

$$
\begin{gathered}
2 \mathrm{H}_{2}+4 \mathrm{OH}^{-} \rightleftarrows 4 \mathrm{H}_{2} \mathrm{O}+4 e^{-} \\
\mathrm{O}_{2}+2 \mathrm{H}_{2} \mathrm{O}+4 e^{-} \rightleftarrows 4 \mathrm{OH}^{-} \\
2 \mathrm{H}_{2}+\mathrm{O}_{2} \rightleftarrows 2 \mathrm{H}_{2} \mathrm{O}
\end{gathered}
$$

Operating with pure hydrogen and oxygen, AFC have the highest energy conversion efficiency of all kinds of fuel cells. The need for very pure gases makes this cell type expensive though, so it is mainly interesting for mobile power supplies in space and submarine boats [6].

\subsection{Hands-on Experiment on AFC $[7,8]$}

In chemistry lessons a simplified alkaline fuel cell can be built and operated by pupils. It is carried out with low-cost materials: a glass container is used as housing; used razor foils are the electrodes and no separator is needed [9]. We use razor foils from the company Braun, because they are covered with a very thin layer of platinum. They serve as low-cost platinum electrodes. It suffices to take used razor foils, so they are subject to "scientific upcycling". Razor foils should not be used in acidic solutions as they contain nickel as core material. In our case the nickel can work as additional catalyst [10]. The procedure is divided in two steps: in the first (preparatory) step hydrogen and oxygen are generated at the electrodes by electrolysis of a slightly alkaline solution by connecting the cell to a $4.5 \mathrm{~V}$ battery. In the second step the AFC is operated by running a load or measuring the voltage under consumption of hydrogen and oxygen. The pupils can closely watch the processes like the formation and consumption of gas bubbles at the razor foil electrodes (Figure 7a).

The experiment is suitable for both, primary and secondary education. Instead of using a battery for the generation of the fuel one could also connect the cell to a small solar panel and power the cell by irradiating the panel.

\subsubsection{Hazards}

Potassium hydroxide solution is slightly caustic. If this experiment is carried out with young pupils, the teachers should fill the potassium hydroxide solution into the glass bottle or use an aqueous solution of baking soda instead.

\subsubsection{Material and Chemicals}

- $4.5 \mathrm{~V}$ battery or alternatively a solar panel and light source

- two cables and

- two alligator clips

- two used razor foils as electrodes

- $100 \mathrm{~mL}$ potassium hydroxide solution, $\mathrm{c}(\mathrm{KOH})=$ $0.1 \mathrm{~mol} / \mathrm{L}$ or aqueous solution of baking soda

- glass container or alternatively a $100 \mathrm{~mL}$ beaker

- optionally cardboard to fix the electrodes (e. g. Figure 6)

- multimeter (U)
- load, for example a sensitive motor.

\subsubsection{Procedure}

Generation of the fuel and the oxidizing agent (Figure 6):

- Fill the potassium hydroxide solution into the glass container.

- Roll the two electrodes and fix them with alligator clips.

- Place the electrodes in the solution ensuring that the alligator clips don't contact the solution.

- Connect the two electrodes via cables with the battery or solar panel until you see many gas bubbles at both electrodes.

- Measure the voltage with the multimeter.

The fuel cell in action:

- Measure the voltage with the multimeter for approximately 10 minutes. OR:

- Connect the two cables with the motor and see how long the motor is running.

- Watch the gas bubbles while the cell is operated.

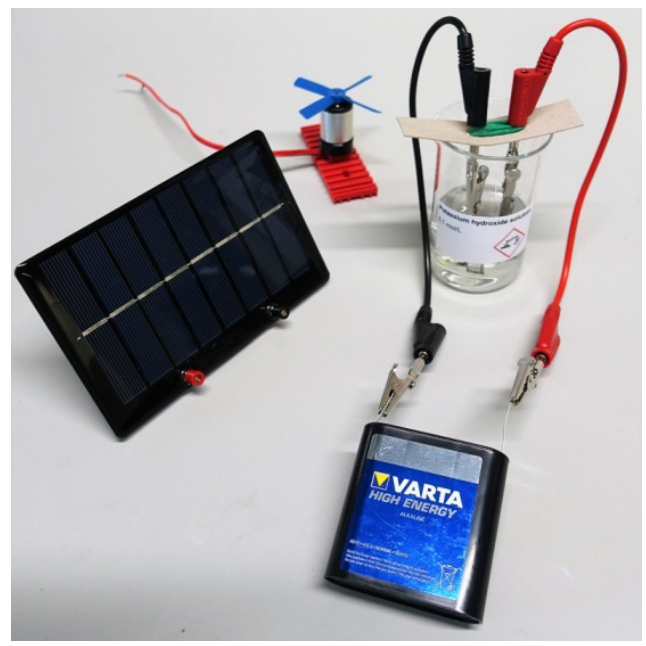

Figure 6. Generation of the fuel via electrolysis with a battery

\subsubsection{Observations}

During electrolysis the formation of colourless gas bubbles at the razor foils' surfaces can be clearly seen. At one razor foil there are obviously more gas bubbles than at the other (Figure 7). After connecting the gas-filled electrodes to the multimeter a voltage about $1 \mathrm{~V}$ can be measured. It decreases slowly over the course of time (Figure 8). The sensitive motor runs several minutes.

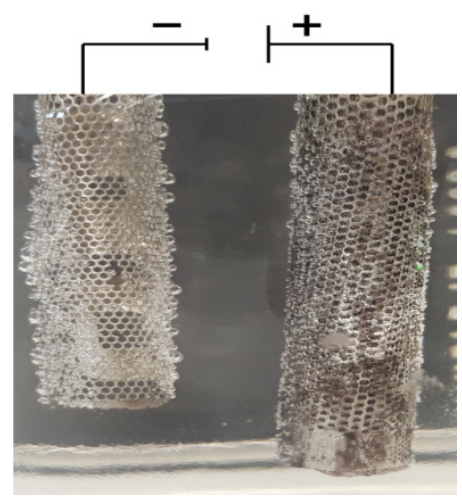

Figure 7. Hydrogen and oxygen gas collected at the electrodes react with each other when the fuel cell is in action 


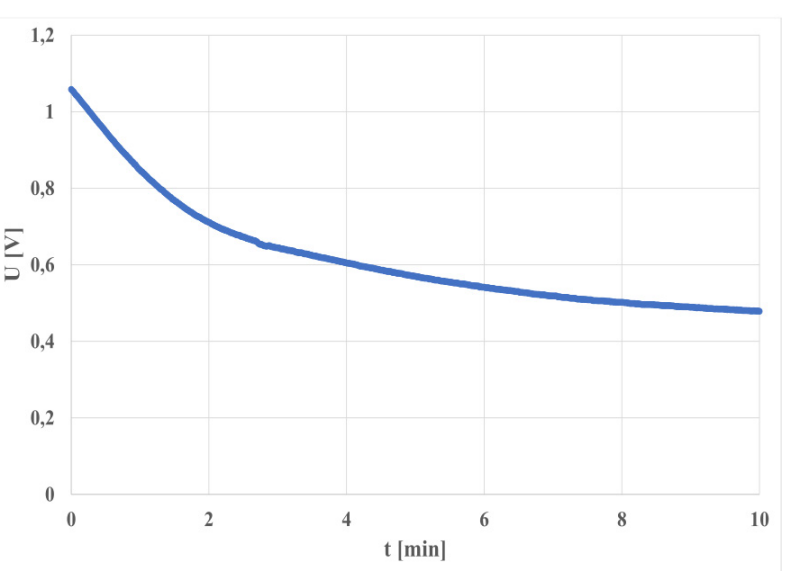

Figure 8. Measured voltage during the reaction of hydrogen and oxygen in the AFC

\subsubsection{Comment}

In the first step water is electrolysed so that the fuel hydrogen is generated at the cathode and oxygen at the anode. Because of the stoichiometry there are twice as many hydrogen molecules generated than oxygen molecules. The gas bubbles are adsorbed at the netlike surfaces of the razor foils.

In the second part of the experiment hydrogen and the oxygen react to form water (eq. 5,6,7). During this process chemical energy is converted into electric energy. The voltage drops when there is no more hydrogen at the electrode. If a motor is connected to the electrodes, it is rotating slowlier over time as the fuel is consumed.

\section{Microbial Fuel Cells (MFC)}

\subsection{Set-up and Working Principle of MFC}

Microbial fuel cells as well as enzymatic fuel cells belong to the group of biological fuel cells. Both types are direct fuel cell systems. In biological fuel cells organic substrates are oxidised with the aid of a biocatalyst. The released electrons move through an external circuit. Both, microbes as well as enzymes, can be used as biocatalysts (Figure 9). In both cell types an organic substrate gets partially or completely oxidised in the anode compartment, the electrons are transferred to the anode and fed into an external circuit. They finally reduce oxygen at the cathode. The anode and cathode compartments are separated for better formation of the potential difference [11]. As a result of numerous possible substrate-catalyst-combinations a great variety of fuel cell systems exists. Therefore, no general valid cell reaction can be formulated.

A great advantage of MFC consists in linking pollutant decomposition with power generation, e.g. in wastewater treatment plants for domestic and industrial wastewater. Moreover, biological fuel cells are used in mobile applications without the risk of volatile or flammable fuels and for desalination of seawater. Small incorporated devices, e.g. cardiac pacemakers operated by blood sugar and sensors for measuring the lactose and glucose concentration linked with automatic drug administration are at the stage of animal testing. The transfer to human beings is subject of current research $[12,13]$.

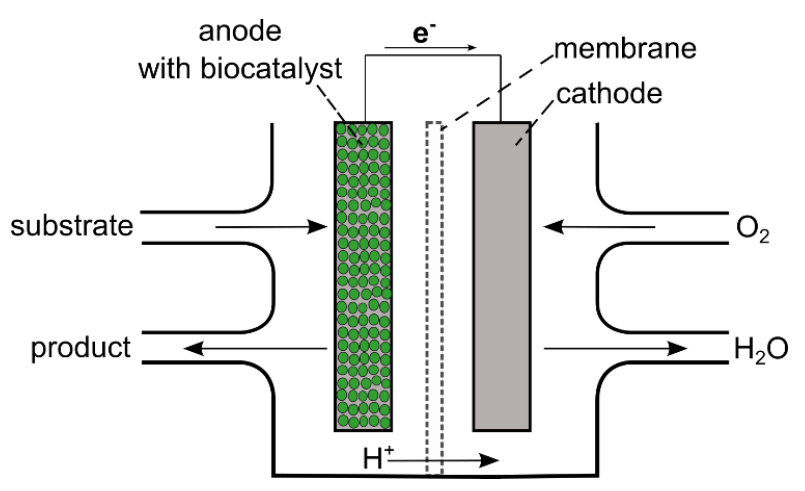

Figure 9. Sketch of a biological fuel cell

\subsection{Hands-on Experiment on MFC [14]}

\subsubsection{Material and Chemicals}

- $100 \mathrm{~mL}$ beaker

- two alligator clips and two cables

- Soxhlet extraction thimble (alternatively piece of an egg box, see Figure 10)

- two iron nails / iron sheets as electrodes

- big paperclip

- multimeter (U)

- dry yeast

- distilled water

- sucrose
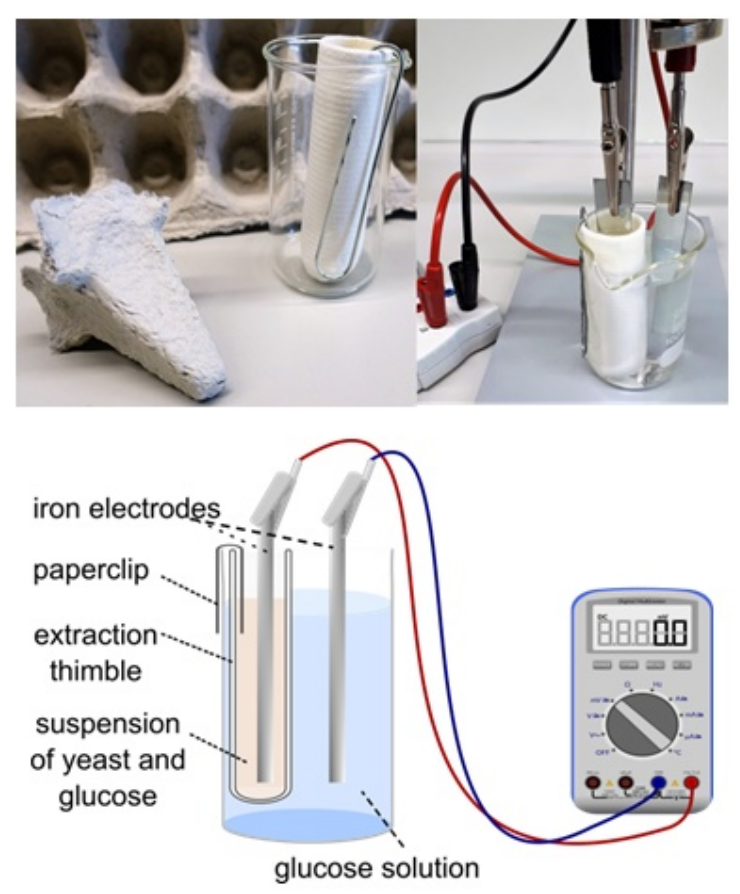

Figure 10. top: Fixing the extraction thimble with a paperclip and set-up; bottom: schematic drawing of the set-up

\subsubsection{Procedure}

- Make a suspension of 1,5 g dry yeast and $25 \mathrm{~mL}$ distilled water.

- Prepare $100 \mathrm{~mL}$ of a sucrose solution, $\mathrm{w}=10 \%$.

- Use the paperclip to fix the Soxhlet extraction thimble/egg box to the inside of the $100 \mathrm{~mL}$ beaker.

- Put the iron electrodes into the cell as shown in Figure 10.

- Fill about $80 \mathrm{~mL}$ sucrose solution into the beaker. 
- Add 2,5 g sucrose to the yeast suspension and fill this mixture into the Soxhlet extraction thimble.

- Start measuring the voltage immediately.

\subsubsection{Observations}

In the yeast suspension colourless gas bubbles are formed that rise to the surface, yielding some foam. A voltage up to $500 \mathrm{mV}$ is measured, that is nearly constant for a period of ten minutes (Figure 11).

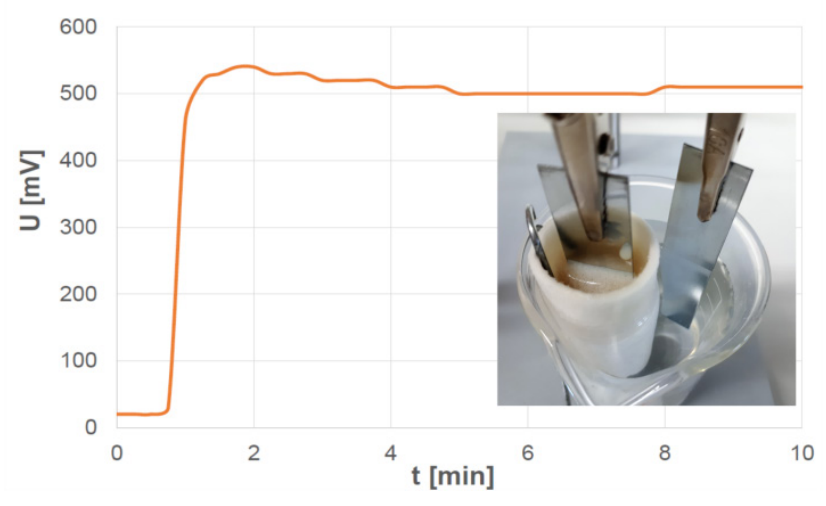

Figure 11. Observation while operating the Yeast FC and diagram of measured voltage in the yeast cell

\subsubsection{Comment}

In the described cell yeast works as a biocatalyst. Baker yeast is suitable for school experiments because it is a harmless, inexpensive everyday product found in every local discounter [15]. Dry yeast can be easily stored and is more effective than fresh yeast. The potential difference and hence the measurable voltage are caused by the yeast's metabolic activity at the anode compartment: sucrose is divided into glucose and fructose. Both are oxidised yielding carbon dioxide that can be observed as gas bubbles. Although side reactions take place, a simplified reaction can be formulated for the school context $[16,17]$.

$$
\mathrm{C}_{6} \mathrm{H}_{12} \mathrm{O}_{6}+6 \mathrm{H}_{2} \mathrm{O} \stackrel{\text { Microbe }}{\longrightarrow} 6 \mathrm{CO}_{2}+24 \mathrm{H}^{+}+24 \mathrm{e}^{-}
$$

Even though most electrons are caught by reduced intermediates, oxygen works as the final electron acceptor within the respiration chain. This is shown by the cathode reaction from eq.9:

$$
6 \mathrm{O}_{2}+24 \mathrm{H}^{+}+24 \mathrm{e}^{-} \rightarrow 12 \mathrm{H}_{2} \mathrm{O}
$$

With decreasing concentration of sucrose in the anode compartment and a decreasing $\mathrm{pH}$ the yeast's metabolic activity falls, so that the voltage declines and finally drops.

\section{Direct Methanol Fuel Cell (DMFC)}

\subsection{Set-up and Working Principle of DMFC}

DMFC are fuel cells driven by alcohol and water at low temperatures $\left(85^{\circ} \mathrm{C}\right)$. In most recent commercial applications methanol is used. The set-up is like that of a hydrogen-driven PEMFC (Figure 4). In these cells, there is also a proton exchange membrane. Methanol reacts directly with water at the anode, forming carbon dioxide, protons and electrons [18]:

$$
2 \mathrm{CH}_{3} \mathrm{OH}+2 \mathrm{H}_{2} \mathrm{O} \rightarrow 2 \mathrm{CO}_{2}+12 \mathrm{H}^{+}+12 \mathrm{e}^{-}
$$

At the cathode oxygen is reduced:

$$
3 \mathrm{O}_{2}+12 \mathrm{H}^{+}+12 \mathrm{e}^{-} \rightarrow 6 \mathrm{H}_{2} \mathrm{O}
$$

The overall reaction is shown in equation 12:

$$
2 \mathrm{CH}_{3} \mathrm{OH}+3 \mathrm{O}_{2} \rightarrow 2 \mathrm{CO}_{2}+4 \mathrm{H}_{2} \mathrm{O}
$$

Although methanol is known as the most electrochemically active organic fuel, it is a thousand times less active than hydrogen [20]. The electric efficiency ranges between 20-30\%. Despite the DMFC system's worse power they have the advantage that methanol is easier to store and transport than the volatile and highly flammable hydrogen $[19,20]$. DMFC are widely used and commercially available. Portable systems are used as battery replacement, as generators and for operating lawnmowers [5].

\subsection{Hands-on Experiment on a DMFC}

\subsubsection{Hazards}

Because methanol is toxic its use at school is strictly regimented. Instead of methanol ethanol can be used as a less dangerous substitute.

\subsubsection{Material and Chemicals}

- two alligator clips

- two used razor foils

- film or similar plastic container

- sponge cloth

- plastic tube

- syringe

- cable tie

- multimeter

- solution I: potassium hydroxide solution, $\mathrm{c}(\mathrm{KOH})=5 \mathrm{~mol} / \mathrm{L}$

- solution II: 1:1 mixture of potassium hydroxide solution $\mathrm{c}(\mathrm{KOH})=5 \mathrm{~mol} / \mathrm{L}$ and methanol or ethanol

\subsubsection{Procedure}

- Prepare the empty film container with a piece of sponge cloth, dividing it into two compartments.

- Roll the two razor foils and attach them to an alligator clip and a cable each.

- Place a small piece of sponge cloth at the plastic tube's end for a better gas dispersion.

- Place the plastic tube into one of the rolled razorfoils.

- Fill solution I in one compartment of the film container section and solution II in the other compartment.

- Place the razor foil with the plastic tube into solution I and the second razor foil into solution II (Figure 12).

- Connect both razor foil electrodes with the multimeter.

- Using the syringe, let air blow slowly through the plastic tube and measure the voltage. 


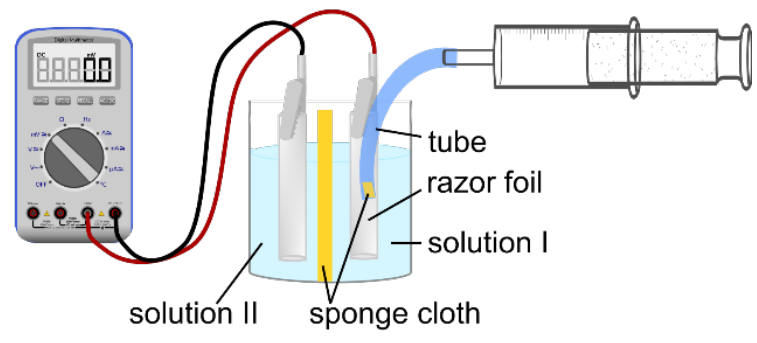

Figure 12. Sketch of a school DMFC (Compare also Figure 3)

\subsubsection{Observations}

When using methanol, a voltage up to $135 \mathrm{mV}$ is measured. Operating the cell with ethanol a similar voltage up to $133 \mathrm{mV}$ is reached. After some time, the voltage decreases in both cases. After ten minutes the voltage of the methanol fuel cell drops to $24 \mathrm{mV}$ and the ethanol fuel cell to $95 \mathrm{mV}$ (Figure 13).

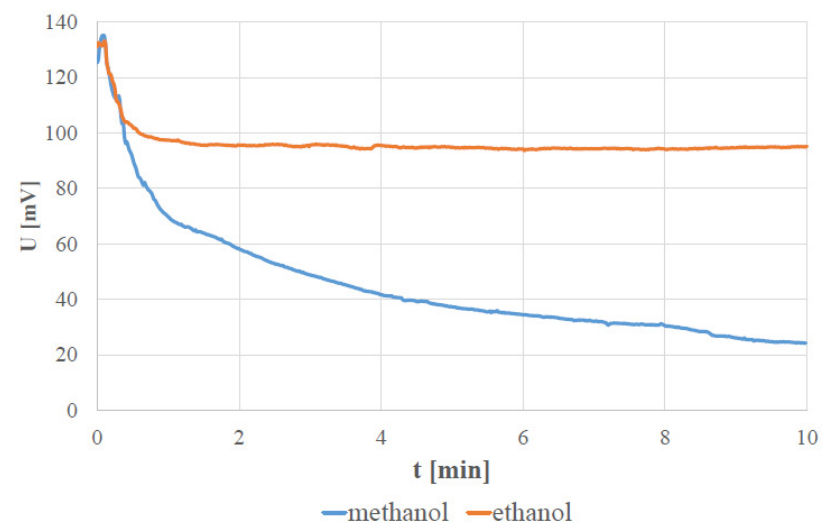

Figure 13. Voltage measured with a methanol and an ethanol fuel cell

\subsubsection{Comments}

Due to the toxicity of methanol it is recommended to substitute methanol by ethanol in this experiment. Both alcohols show the operating principle of this kind of fuel cell, which could more generally be called direct alcohol fuel cell (DAFC) [21]. In this setting the expensive proton exchange membrane is replaced by a low-cost sponge cloth.

When using methanol as a fuel, it partially migrates to the cathode compartment, a so-called methanol crossover takes place. As a consequence, methanol reacts in undesirable side reactions at the cathode, too, and a mixed potential appears so that the voltage decreases. Using ethanol, the crossover is a hundred times smaller [19].

It is estimated that in the future direct alcohol fuel cells will be increasingly important as energy converters, e.g. for charging mobile devices [18].

\section{Supplemental Material [22]}

As fuel cells are an important topic for teaching sustainable energy in the chemistry classroom, they are also dealt with during teacher training at university. Here we give a short insight into a digital learning tool (as interactive PowerPoint tool) created by a student in our work group at the University of Tuebingen in 2018. It is suggested to use it in the context of electrochemistry in year 11 or 12 . The tool aims at giving an insight into different kinds of fuel cells, in this case a fuel cell based on kitchen equipment, an AFC, a MFC, a DMFC and a PEMFC, and their operating principles. The tool is designed as a learning sequence that takes between 4-6 hours, so that it may be situated in a project. The tool contains information, animations and experimental instructions on different kinds of fuel cells. The contents are embedded in a story. Two students explore the topic fuel cells, partially helped by the fictional Professor Schönfuß. In each section, first facts on the respective type of fuel cell are presented, followed by experimental instructions, explanations with animations on the particle level (Figure 14) and some tasks.
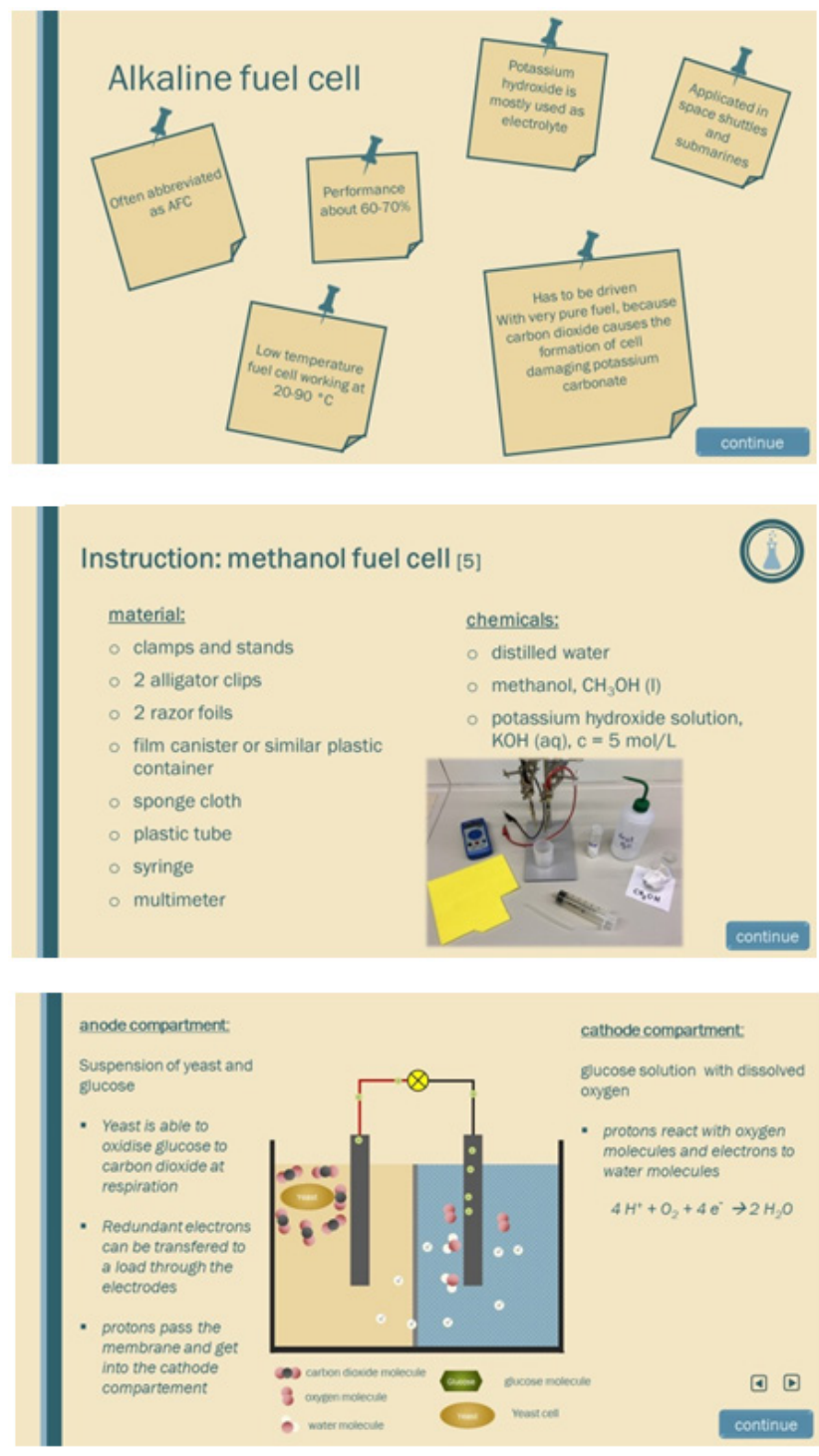

Figure 14. top: collection of facts on the AFC; middle: part of an experimental instruction; bottom: part of an animation at the particle level

A supplemental text document as handout for teachers describes how the tool is organised and how to use it at school.

\section{Conclusion}

Fuel cells as examples of sustainable energy solutions are an important topic to impart ideas of ecological 
sustainability at school. In our contribution we presented simple and low-cost hands-on experiments for students in secondary education to show the diversity of different kinds of fuel cells and their working principles in general. The experiments can be integrated in chemistry lessons in the context of electrochemistry. Also an interdisciplinary approach is possible, e.g. in cooperation with physics (focus on the performance of different kinds of fuel cells) or in cooperation with biology (focus on MFC and microbes). Furthermore, an interdisciplinary humanistic setting would be interesting where the interrelation between fuel cells and the UN's 17 goals of sustainability could be discussed.

Additionally, we gave a short insight into a digital learning tool on fuel cells, which is currently translated from German into English and that we would provide interested readers with on request.

\section{References}

[1] https://sustainabledevelopment.un.org/?menu=1300. 06.01.2019.

[2] https://www.globalgoals.org/resources\#icons-for-the-goals. 01.12 .2018 .

[3] Transforming our world: the 2030 Agenda for Sustainable Development, A/RES/70/1, 21.10.2015.

[4] Fang, T. P., Halim, L., Ramli Wan Daud, W., Shahbudin Masdar, M. (2017). How ready is renewable energy? A review on renewable energy and fuel cell teaching in schools. 7th World Engineering Education Forum, WEEF 2017, 236-244.

[5] Kurzweil, P., Schmid, O. (2016). Brennstoffzellentechnik. Grundlagen, Materialien, Anwendungen, Gaserzeugung, 3. Aufl. Springer Vieweg, Wiesbaden.

[6] Vanussi Melo Guaitolini, S., Yahyaoui, I., Fardin, J. F., Frizera Encarnacao, L., Tadeo, F. (2018). A review of fuel cell and energy cogeneration technologies. 9th International Renewable Energy Congress (IREC), 1-6.

[7] Tausch, M., Wachtendonk, M. von (Hrsg.) (2011). Chemie 2000+. Sekundarstufe I: Gesamtband. Nordrhein-Westfalen, 2. Aufl. Buchner, Bamberg.
[8] Tausch, M., Wachtendonk, M. von (Hrsg.) (2007). Chemie 2000+. Sekundarstufe II: Gesamtband. Nordrhein-Westfalen. Buchner, Bamberg.

[9] Bohrmann-Linde, C. (2004). Von der Elektrolysezelle zur Leuchtdiode - Elektrolumineszenz im Chemieunterricht. Praxis der Naturwissenschaften - Chemie in der Schule 3/53, 12-19.

[10] Ryan, L. (2015). Advanced Chemistry for you, 2. Aufl. OUP, Oxford.

[11] Logan, B. E., Hamelers, B., Rozendal, R., Schröder, U., Keller, J., Freguia, S., Aelterman, P., Verstraete, W., Rabaey, K. (2006). Microbial fuel cells: methodology and technology. Environmental Science \& Technology 40/17, 5181-5192.

[12] Kumar, R., Singh, L., Zularisam, A. W., Hai, F. I. (2018). Microbial fuel cell is emerging as a versatile technology. A review on its possible applications, challenges and strategies to improve the performances. Int J Energy Res 42/2, 369-394.

[13] Santoro, C., Arbizzani, C., Erable, B., Ieropoulos, I. (2017). Microbial fuel cells. From fundamentals to applications. A review. Journal of power sources 356, 225-244.

[14] Zückert, R., Bohrmann-Linde, C. (2018). Die biologische Brennstoffzelle im Chemieunterricht - Einfache Experimente mit kostengünstigen Materialien. CHEMKON accepted.

[15] Silveira, G., Ikegaki, M., Schneedorf, J. M. (2016). A low-cost yeast-based biofuel cell. An educational green approach. Green Chemistry Letters and Reviews 10/1, 32-41.

[16] Babanova, S., Hubenova, Y., Mitov, M. (2011). Influence of artificial mediators on yeast-based fuel cell performance. Journal of bioscience and bioengineering 112/4, 379-387.

[17] Bennetto, H. P. (1990). Electricity generation by microorganisms. Biotechnology Education 1/4, 163-168.

[18] Khuhro, A. A., Ali, Y., Najam-Uddin, M., Khan, S. (2018). A Technological, Economical and Efficiency Review of Direct Methanol Fuel Cell. iCoMET 2018, 1-4.

[19] Bertau, M., Räuchle, K., Offermanns, H. (2015). Methanol - die Basischemikalie. Chemie in unserer Zeit 49/5, 312-329.

[20] Olah, G. A., Goeppert, A., Prakash, G. K. S. (2018). Beyond Oil and Gas. The Methanol Economy, 3. Aufl. John Wiley \& Sons Incorporated, Newark.

[21] Sahu, O. P., Basu, S. (2014). Direct Alcohol Alkaline Fuel Cell as Future Prospectus. Advanced Energy: An International Journal (AEIJ) 1/1, 43-52.

[22] Jauch, L. (2018). Interactive ppt-tool on fuel cells (Thesis University of Tuebingen). http://chemiedidaktik.uniwuppertal.de/index.php?id=4214\&L=1 (22.03.2019). 